\title{
Hashimoto's Thyroiditis in children and adolescents: at presentation and during long-term follow up
}

You Jin Kim, Hae Sang Lee, Jin Soon Hwang

From 7th APPES Biennial Scientific Meeting

Nusa Dua, Bali. 14-17 November 2012

\section{Objective}

Hashimoto's thyroiditis (HT) is the most common cause of goiter and acquired hypothyroidism in children and adolescents. The aim of this study was to evaluate the clinical manifestations of HT leading to referral in children and adolescents, in addition to disease course and long-term outcome.

\section{Methods}

The clinical and laboratory data of 57 patients with HT at presentation and long-term outcome were retrospectively evaluated using patient records.

\section{Results}

The mean age of the patients at the time of diagnosis was $10.9 \pm 2.3$ years and female/male ratio was $49 / 8$. The complaint at the time of hospital presentation was goiter in $66.7 \%$ of the patients. Other reasons for referral were clinical symptoms of hypothyroidism (7.1\%) and findings on work-up for an unrelated problem $(24.6 \%)$ or for high-risk groups (1.8\%). At baseline, 49.1\% $(\mathrm{n}=28)$ of the patients were euthyroid, whereas $31.6 \%(n=18)$ had subclinical hypothyroidism, $10.5 \%(\mathrm{n}=6)$ of subjects were evaluated as hypothyroid. Out of 57 patients, 5 were diagnosed with hashitoxicosis. Five of the 28 subjects, who were initially euthyroid developed subclinical or overt hypothyroidism during the follow-up period and were started on thyroid medication.

\section{Conclusions}

Thyroid function tests should be repeated periodically to detect progression to hypothyroidism in

Department of Pediatrics, Ajou University School of Medicine, Ajou University Hospital, Suwon, Korea initially euthyroid patients as well as reversibility of hypothyroidism.

Published: 3 October 2013

doi:10.1186/1687-9856-2013-S1-P143

Cite this article as: Kim et al:: Hashimoto's Thyroiditis in children and adolescents: at presentation and during long-term follow up.

International Journal of Pediatric Endocrinology 2013 2013(Suppl 1):P143.
Submit your next manuscript to BioMed Central and take full advantage of:

- Convenient online submission

- Thorough peer review

- No space constraints or color figure charges

- Immediate publication on acceptance

- Inclusion in PubMed, CAS, Scopus and Google Scholar

- Research which is freely available for redistribution
C Biomed Central 